\title{
Iatrogenic nutritional effects of anticonvulsants
}

By E. H. Reynolds, Department of Neurology, Institute of Psychiatry and King's College Hospital Medical School, London SE5 $8 A F$ and MRC Clinical Research Centre, Harrow, Middlesex

The three major anticonvulsants currently used for the treatment of grand mal and focal epilepsy are phenobarbitone (introduced into therapy in 1912), diphenylhydantoin (DPH) (introduced in 1938), and primidone (introduced in 1952). Fig. I illustrates the common structural features of these drugs, which presumably account for their common anticonvulsant properties and side-effects. There are several other anticonvulsants which, for the most part, are structurally related to these three major drugs to which I will confine my discussion. It is important to note that primidone exerts its therapeutic and toxic effects, at least in part, by its conversion in vivo to phenobarbitone.

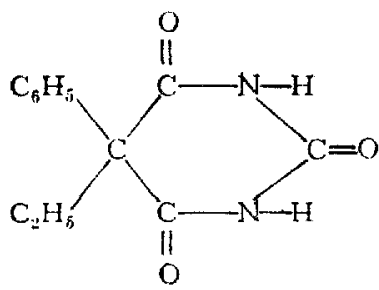

(a)

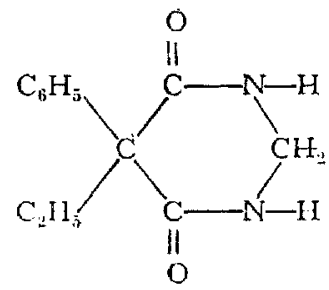

(b)

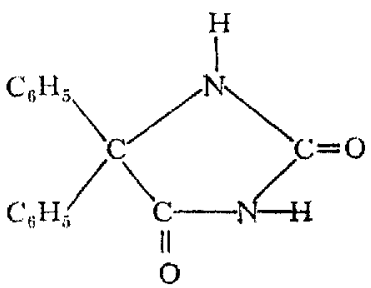

(c)

Fig. I. Structural relationships of major anticonvulsants: (a) phenobarbitone; (b) primidone; (c) diphenylhydantoin.

It is doubtful whether there is any class of drugs which presents more serious problems of chronic nutritional side-effects than is presently the situation with these anticonvulsants. There are several reasons which may account for this.

(I) Although epilepsy may begin at any age, in three out of four patients it does so before the age of 20 , usually in infancy or early adolescence. Despite anticonvulsant therapy, seizures are a recurring problem in the majority of patients, in whom drug therapy must therefore be lifelong.

(2) As epilepsy occurs in approximately one in 200 of all populations that have been studied (there are estimated to be 300,000 patients in Great Britain alone) it will be apparent that anticonvulsants are amongst the most widely consumed of all drugs. Certainly there are no drugs which are taken for more prolonged periods of 
time. It is commonplace in neurological or seizure clinics to find patients who have been taking phenobarbitone for $4^{0-50}$ years, DPH for $20-30$ years or primidone for 20 years.

(3) Many of these patients take several drugs, which summate or interact in various ways.

(4) In some patients, who are on the threshold, chronic toxicity may be precipitated by the additional burdens of dietary deficiency, pregnancy, intercurrent illness, or institutionalization.

It is perhaps not surprising, therefore, that there has been growing recognition of an increasing number of chronic toxic effects of these drugs in the last few years. This subject has been reviewed in detail by Reynolds (1974). Here I will summarize some of the more important complications, especially of nutritional interest (Table 1).

\section{Table I. Nutritional effects of anticonvulsants}

Folic acid deficiency

Neonatal coagulation defects

Metabolic bone disease: vitamin $\mathrm{D}$ deficiency

Connective tissue disorders

Liver enzyme induction

Endocrine effects

Pyridoxine deficiency (?)

Heavy metal disturbances (?)

\section{Folic acid deficiency}

Megaloblastic anaemia due to folic acid deficiency was not recognized as a complication of anticonvulsant therapy until 1952. For some years it was then regarded as a curious, rare (between 0.15 and $0.75 \%$ of patients) and unimportant side-effect, of more interest to haematologists than neurologists. However, in the last decade, with the development of microbiological assays for folic acid in blood, it has become apparent from many studies (see Reynolds, 1972, 1974) that mild to moderate deficiency of this vitamin is detectable in the majority (approximately $55 \%$ ) of non-anaemic epileptic patients on drug therapy, as reflected by low serum and erythrocyte folic acid levels. It is only in the more severely deficient patients that a megaloblastic anaemia occurs, in some because of the added problem of dietary deficiency.

Phenobarbitone, primidone and especially DPH have all been incriminated, but the mechanism by which the drugs affect folic acid metabolism is still unknown. Hypotheses that have been proposed are: (I) competitive interaction between the drugs and folic acid co-enzymes; (2) malabsorption of folic acid; (3) induction of hepatic enzymes involved in folic acid metabolism; (4) increased demand for folic acid either for hydroxylation of anticonvulsant drugs or for other hepatic enzymes induced by the drugs.

This complication of therapy has focused attention on the previously neglected subject of folic acid metabolism in the nervous system, particularly as the druginduced deficiency is accompanied by a corresponding fall of cerebrospinal fluid 
folic acid levels in epileptic patients (Reynolds, Gallagher, Mattson, Bowers \& Johnson, 1972) and because there is increasing evidence, both experimental and clinical, that the vitamin and its derivatives have potent convulsant properties, and may reverse the anticonvulsant effects of the drugs (Obbens, 1973; Reynolds, 1973). It is therefore possible that the antifolate and antiepileptic actions of the drugs are at least partially related (Reynolds, 1973). Another hypothesis that is currently being investigated is that the drug-induced folic acid deficiency contributes to some of the chronic neurological complications of the drugs, especially mental symptoms (Reynolds, 1974).

The metabolism of folic acid is closely linked with that of cyanocobalamin, but cyanocobalamin levels are only occasionally subnormal in epileptic patients on drugs. Low cyanocobalamin levels may be precipitated by treatment with folic acid, the significance of which is uncertain (Chanarin, 1969; Reynolds, 1972).

\section{Neonatal coagulation defects}

Depression of vitamin $\mathrm{K}$-dependent coagulation factors $(2,7,9$, and ro) has been found in up to $50 \%$ of neonates born to epileptic mothers on drugs, and sometimes this deficiency leads to bleeding which is indistinguishable from haemorrhagic disease of the newborn, and which is preventable or correctable with vitamin $\mathrm{K}$ (Mountain, Hirsch \& Gallus, 1970; Solomon, Hilgartner \& Kutt, I972). The mechanism is uncertain, but the neonate has little transplacental and no exogenous source of vitamin $\mathrm{K}$, has immature enzyme systems, and is presumably sensitive to drugs such as phenobarbitone and DPH which are metabolized in the liver.

\section{Metabolic bone disease : vitamin $D$ deficiency}

Several reports have confirmed the earlier observations of Kruse (1968) and Dent, Richens, Rowe \& Stamp (I970) of radiological and biochemical evidence of rickets or osteomalacia in up to one-third of drug-treated epileptics. The biochemical evidence includes slight hypocalcaemia and moderate elevation of serum alkaline phosphatase. Relatively few patients have clinical symptoms such as pain, fractures or weakness.

The mechanism is again uncertain, but there is evidence to support the hypothesis of Dent et al. (1970) that phenobarbitone and DPH induce enzymes in the liver which divert the metabolism of vitamin $D$ to its more polar and inactive metabolites (Stamp, 1974). Low levels of serum 25-hydroxycholecalciferol have been reported in a British (Stamp, Round, Rowe \& Haddad, 1972) and an American (Hahn, Hendin, Scharp \& Haddad, I972) study, and patients respond to treatment with vitamin D (Christiansen, Rødbro \& Lund, 1973), and especially with hydroxycholecalciferol (Stamp et al. 1972). Other possible mechanisms have yet to be excluded (Reynolds, 1974), and the German workers have emphasized an effect of DPH on calcium absorption (Schaefer, von Herrath \& Kraft, I973). 


\section{Connective tissue disorders}

Subtle effects of the drugs on connective tissue are suggested by the well-known DPH-induced gum hypertrophy, and also by the high prevalence of facial skin changes (Lefèbvre, Haining \& Labbé, 1972; Walshe, 1972) and Dupuytren's contracture (Pojer, Radivojevic \& Williams, r972) in drug-treated patients. The mechanisms are unknown but there is some evidence, albeit conflicting, to support suggestions that the drugs affect collagen metabolism and fibroblast proliferation (Houck, Cheng \& Waters, 1972) and that liver enzyme induction may be relevant (Pojer et al. 1972).

\section{Liver enzyme induction}

It is well known that phenobarbitone and DPH induce liver microsomal enzymes experimentally, but the implications of this for the metabolism of epileptic patients who take these drugs over many years are only just beginning to be studied. Hunter, Maxwell, Carrella, Stewart \& Williams (1971) reported that urinary D-glucaric acid excretion is a quantitative measure of drug-induced microsomal enzyme activity and is increased in proportion to the dose of drug therapy in nearly all epileptic patients. The inducing effects may be important in epileptics in relation to vitamin $D$ deficiency (Dent et al. 1970), altered steroid metabolism (see below), drug interactions (Mannering, 1972), and bilirubin excretion (Thompson, Eddleston \& Williams, I969). It is probable that other metabolic consequences of this phenomenon will be uncovered.

\section{Endocrine effects}

Phenobarbitone and, in particular, DPH affect pituitary and adrenal function (Woodbury, 1958; Werk, MacGee \& Sholiton, 1964; Rinne, 1966). DPH also interferes with thyroid function (Oppenheimer \& Tavernetti, 1962; Chin \& Schussler, I968) and has mild diabetogenic properties resulting from impairment of the release of insulin in response to glucose stimulation (Malherbe, Burrill, Levin, Karam \& Forsham, 1972). It seems that DPH may interfere with the release of many different hormones, possibly by a common but unidentified mechanism (Reynolds, 1974). Although epileptic patients are not strikingly prone to endocrine disorders, there has been very little clinical research, and subtle effects may be overlooked.

\section{Pyridoxine and heavy metals}

Although various indices of pyridoxine metabolism are reported to be abnormal in $20-50 \%$ of epileptic patients, the role of drugs in this phenomenon requires clarification (Reynolds, 1974). A probable effect of anticonvulsants on copper and zinc metabolism (Peters, Eichman, Price, Kozelka \& Reese, rg66; Cantu \& Schwab, r966) also awaits detailed study. 


\section{Conclusion}

In view of the many years over which epileptic patients take their medication, it is hardly surprising that chronic nutritional side-effects occur, but it is surprising that it has taken so long for these problems to be recognized when the evidence now suggests they must have been present in earlier decades, i.e. 1940's and 1950's at least. Many factors probably account for this oversight, but one must be a general failure to face up to the almost inevitable consequences of such prolonged therapy. Hopefully the new insight into these complications will lead to prophylactic measures, improvement in the quality of treatment for epileptic patients, and greater alertness in detecting and preventing chronic nutritional problems in other fields of drug therapy.

\section{REFERENCES}

Cantu, R. C. \& Schwab, R. S. (I966). Trans. Am. neurol. Ass. 91, 201.

Chanarin, I. (1969). The Megaloblastic Anaemias. Oxford: Blackwell.

Chin, W. \& Schussler, G. C. (1968). F. clin. Endocr. Metab. 28, I81.

Christiansen, L., Rødbro, P. \& Lund, M. (1973). Br. med. \%. iv, 695 .

Dent, C. E., Richens, A., Rowe, D. J. F. \& Stamp, T. C. B. (1970). Br. med. F. iv, 69.

Hahn, T. J., Hendin, B. A., Scharp, C. R. \& Haddad, J. G. (1972). New Engl. F. Med. 287, 900.

Houck, J. C., Cheng, R. F. \& Waters, M. D. (1972). In Antiepileptic Drugs p. 267 [D. M. Woodbury, J. K. Penry and R. P. Schmidt, editors]. New York: Raven Press.

Hunter, J., Maxwell, J. D., Carrella, M., Stewart, D. A. \& Williams, R. (197 I). Lancet i, 572.

Kruse, R. (1968). Mschr. Kinderheilk. 116, 378.

Lefèbvre, E. B., Haining, R. G. \& Labbé, R. F. (1972). New Engl. F. Med. 286, 1301.

Malherbe, C., Burrill, K. C., Levin, S. R., Karam, J. H. \& Forsham, P. H. (1972). New Engl. F. Med. 286, 339 .

Mannering, G. J. (1972). In Antiepileptic Drugs p. 23 [D. M. Woodbury, J. K. Penry and R. P. Schmidt, editors]. New York: Raven Press.

Mountain, K. R., Hirsch, J. \& Gallus, A. S. (1970). Lancet i, 265.

Obbens, E. A. M. T. (1973). Experimental epilepsy induced by folate derivatives. PhD Thesis, University of Nijmegen.

Oppenheimer, J. H. \& Tavernetti, R. R. (1962). F. clin. Invest. 4I, 2213.

Peters, H. A., Eichman, P. L., Price, J. M., Kozelka, F. L. \& Reese, H. H. (1966). Dis. nere. Syst. 27. 97.

Pojer, J., Radivojevic, M. \& Williams, T. F. (1972). Archs intern. Med. 129, 561.

Reynolds, E. H. (1 972). In Antiepileptic Drugs p. 247 [D. M. Woodbury, J. K. Penry and R. P. Schmidt, editors]. New York: Raven Press.

Reynolds, E. H. (1973). Lancet i, 1376.

Reynolds, E. H. (1974). Epilepsia (In the Press.)

Reynolds, E. H., Gallagher, B. B., Mattson, R. H., Bowers, M. \& Johnson, A. L. (1972). Nature, Lond. 240, I55.

Rinne, U. K. (1966). Confinia neurol. 27, 431 .

Schaefer, K., von Herrath, D. \& Kraft, D. (1973). Dt. med. Wschr. 98, r043.

Solomon, G. E., Hilgartner, M. W. \& Kutt, H. (1972). Neurology, Minneap. 22, i 165.

Stamp, T. C. B. (1974). Proc. R. Soc. Med. 67, 64.

Stamp, T. C. B., Round, J. M., Rowe, D. J. F. \& Haddad, J. G. (1972). Br. med. J. iv, 9.

Thompson, R. P. H., Eddleston, A. L. W. F. \& Williams, R. (I969). Lancet i, 2 r.

Walshe, M. M. (1972). Trans. a. Rep. St Fohn's Hosp. derm. Soc. Lond. 58, 269.

Werk, E. E. Jr, MacGee, J. \& Sholiton, L. J. (1964). F. clin. Invest, 43, 1824.

Woodbury, D. M. (1958). Pharmac. Rev. ro, 275. 